PREGLEDNI RAD

UDK: 687:502.131.1

Izv. prof. dr. sc. Mislav Ante Omazić*

Dr. sc. Alica Grilec **

Doc. dr. sc. Irena Šabarić ${ }^{* * *}$

\title{
RAZVOJ KONCEPTA ODRŽIVOG RAZVOJA U MODNOJ INDUSTRIJI - PREGLED LITERATURE
}

\author{
DEVELOPMENT OF THE SUSTAINABLE DEVELOPMENT \\ CONCEPT IN FASHION INDUSTRY - LITERATURE REVIEW
}

SAŽETAK: Ovaj rad istražuje probleme vezane uz koncept održivosti u modnoj industriji s ciljem izgradnje teorijske platforme za bolje razumijevanje sadašnjih i budućih trendova istraživanja. Proizvodnja tekstila, odjeće i obuće koja danas predstavlja ključne elemente modne industrije, prema različitim izvorima smatra se jednim od najvećih zagađivača na svijetu. Zbog toga u modi postoji stalna potreba za primjenom različitih koncepata održivog razvoja kao odgovora na koncept "brze" mode koji počiva na konzumerizmu, potrošnji i kratkom životnom vijeku proizvoda. Postoji velik broj primjera u modnoj djelatnosti koji ističu probleme i pozitivne primjere primjene koncepta održivog razvoja u modi, ali još uvijek općenito vlada nedostatak potrebe uravnoteženosti okolišnih, socijalnih i ekonomskih ciljeva. Kao protuteža takozvanoj brzoj modi ranih 1970-ih rodio se društveni pokret održivog pristupa modi koji objedinjuje eko dizajn, nove tehnologije izrade vlakana, recikliranje, savjesnu potrošnju te ostale elemente koji zajednički čine takozvanu sporu modu. U zaključku rada iznesene su smjernice budućega istraživanja održivih modnih poduzeća u Republici Hrvatskoj. $\operatorname{moda}^{2}$.

KLJUČNE RIJEČI: modna industrija, održivi razvoj, održivost, brza moda ${ }^{1}$, spora

SUMMARY: This paper explores sustainability issues in the fashion industry with the aim of building a theoretical platform for a better understanding of current and future

Izv. prof. dr. sc. Mislav Ante Omazić, Sveučilište u Zagrebu, Ekonomski fakultet, Hrvatska, Trg J.F. Kennedyja 6, 10000 Zagreb, E-pošta: momazic1@efzg.hr

** Dr. sc. Alica Grilec, Sveučilište u Zagrebu, Tekstilno-tehnološki fakultet, Hrvatska, Prilaz baruna Filipovića 28a, 10000 Zagreb, E-pošta: alica.grilec@ttf.hr

*** Doc. dr. sc. Irena Šabarić, Sveučilište u Zagrebu, Tekstilno-tehnološki fakultet, Hrvatska, Prilaz baruna Filipovića 28a, 10000 Zagreb, E-pošta: irena.sabaric@ttf.hr

Engl. fast fashion.

Engl. slow fashion. 
research trends. Textile, clothing and footwear production today are key elements of the fashion industry and are considered one of the world's largest polluters. Because of this, there is a constant need for applying different concepts of sustainable development as a response to the concept of "fast" fashion. There are many links that point out the problems and positive examples of applying the concept of sustainable development in the fashion industry, but there is still a lack of human consciousness on ecological, social and economic problems. As a counterweight to the so-called fast fashion of the early 1970s, a social movement of sustainable approaches was created that combine eco-design, new fiber-making technology, recycling, conscientious consumption and other things associated with modern approach to fashion that puts all its elements in balance. In the conclusion of the paper, the guidelines for future research of sustainable fashion companies in the Republic of Croatia were presented.

Key words: fashion industry, sustainable development, sustainability, fast fashion, slow fashion

\section{UVOD}

Prema Wilsonu (2010.) modna industrija se razlikuje od ostalih grana prerađivačke industrije jer na nju i na njen krajnji proizvod snažno utječe promjena te bi se modna industrija vrlo jednostavno mogla opisati kao industrija izrade odjeće. To bi izostavilo važnu razliku između mode i njezinoga rezultata koji podrazumijeva da sama odjeća uključuje svoju funkcionalnu stranu kao jednu od temeljnih osnovnih potreba čovjeka, dok moda uključuje vlastite predrasude stila, individualnoga ukusa, dizajna i kulturne evolucije. Nadalje, Wilson (2010.) navodi kako je upravo ono što definira modnu djelatnost temeljeno na funkcijama i položajima pojedinaca koji djeluju unutar nje, a to su dizajneri, proizvođači uzoraka, trgovine, radnici u tvornicama, švelje, krojači, novinari, publicisti, prodajno osoblje, modeli, proizvođači tekstila te umjetnici, kao i mnogi drugi koji su (in)direktno povezani. Kawamura (2010.) ističe da je cjelokupno poimanje mode doživjelo prekretnicu u jednoj točki u povijesti modne djelatnosti. Prema njemu, nakon industrijske revolucije, izrada odjeće postala je zrela industrija potpomognuta tehnološkim napretkom koji je doveo do razvoja tvornica za proizvodnju velikih razmjera, a proizvodnja se razvila na svim područjima vezanim uz tekstil i odjeću te je toliko ubrzala da je početkom 20-og stoljeća postalo moguće proizvesti tekstil i velike količine tekstila izrazito velikom brzinom. Jednako tako je bilo moguće brzo, troškovno efikasno i jednostavno proizvesti vjerne kopije skupljeg dizajna te se na taj način širokim potrošačkim masama omogućilo da nose isto što i oni koji su odjeveni po posljednjem trendu. Kawamura (2010.) također navodi kako su prije masovne proizvodnje, anonimni proizvođači odjeće, a ne dizajneri, davali značajan doprinos širenju mode, iako javnost nije bila u potpunosti svjesna njihovoga postojanja. Nadalje, važno je istaknuti kako je modna djelatnost izrazito brza i propulzivna te ono što se smatra modno prijemčljivim jedan dan, već idući dan to više nije, a modnim markama predstoji velik izazov da odgovore na stalne promjene te da uspješno komuniciraju svoje ideje i dizajn kako bi stvorili lojalne kupce (Moore, 2012.).

Promjena i brzina koje su povezane s modnom djelatnosti, dovele su do termina "brze mode" koju obilježavaju niske cijene koje stimuliraju kupce na pretjeranu konzumaciju 
mode na štetu kvalitete proizvoda te rezultiraju odjećom koja se može nositi ograničen broj puta jer im upravo loša kvaliteta ne dopušta više pranja (Jung, Jin, 2014.). Koncept brze mode se prije svega odnosi na ubrzani proizvodni ciklus i smanjeni životni vijek modnih predmeta. Ovaj koncept kao takav utječe na temelje modne djelatnosti pa tako, između ostalog, briše granice između pojedinih sezona pa se dovodi u pitanje i predstavljanje pojedinih linija na za to predviđenim tradicionalnim modnim događanjima. Sve zajedno, od same proizvodnje takvih proizvoda pa do odlaganja nakon prestanka korištenja izravno utječe na održivost okoliša. Jedan od ključnih aspekata koji je utjecao na razvoj koncepta brze mode jest globalizacija i inovacije u menadžmentu lanca dobave među suparnicima na modnom tržištu. Iz perspektive prodavača ovakav pristup modi potiče kupce da često posjećuju prodajna mjesta i kupuju s većom frekvencijom.

Kako bi se se smanjilo onečišćenje okoliša izazvano djelatnostima povezanim s modom, sve veći vodećih poslovnih organizacija koje se bave proizvodnjom i prodajom mode i modnih dodataka poput Patagonia-e, G-Star Raw-a, North Face-a i Toms-a počelo je temeljiti vlastitu konkurentnost na konceptu održivosti pozorno prateći održivost svakog koraka stvaranja dodatne vrijednosti. Pored ovih poduzeća i mnogi modni dizajneri su sve glasnije počeli zagovarati održiviji, sporiji pristup modi, a najistaknutija među njima je Stella McCartney. Čak su i neki od najvećih zagovornika brze mode poput H\&M-a ili ASOS počeli razvijati zasebne linije poput H\&M Conscious Collection ili ASOS Eco Edit; a mnogi start-upovi su prepoznali tržišnu nišu i kroz svoje inovativne modele odgovorili na neke od izazova u lancu stvaranja vrijednosti poput United by Blue, Edun, Uniforms for the Dedicated ili Mud Jeans. Na kraju neke od kompanija pokušavaju biti lideri na svojim tržištima pa se Puma, Adidas, New Balance i Nike natječu u prezentaciji održivosti svojih poslovnih modela.

Tako je gotovo svima njima ključan cilj postao produljiti životni ciklus modnog proizvoda dizajniranjem proizvoda po konceptu takozvane spore mode te izravno utjecati na potrošače da prestanu s konzumacijom prozvoda koji za vrlo kratko vrijeme završe u okolišu kao otpad. Ozbiljnost problema i koncept održivosti kao odgovor, privukli su zanimanje znanstvenika. Stoga, radi pružanja jasnih smjernica za buduća istraživanja vezana uz koncept održivog razvoja u modnoj industriji, ovaj je rad usmjeren na pregled postojećih istraživanja te sintetiziranje glavnih pristupa i zaključaka. Konkretno, ovaj pregled nastoji prikazati postojeće studije (objavljene u razdoblju od 2010. - 2017., Science Direct baza podataka; pretražujući u: časopisima o poslovanju, upravljanju i računovodstvu, ekonomiji, ekonometrici i financijama, okolišnim i društvenim znanostima) s obzirom na njihovu:

1) razinu analize

2) fokus istraživanja

3) vrstu rada/istraživanja

4) veličinu uzorka

5) analizirane odnose.

Sam članak je strukturiran na način da se nakon uvodnoga poglavlja ukratko opisuje koncept održivog razvoja u modnoj djelatnosti te se pruža niz dostupnih definicija važnih za razumijevanje koncepta održive modne industrije. U sljedećem poglavlju se navode različite vrste izvora u kojima su se studije o različitim elementima održivosti pojavile dosada, dok se četvrtim poglavljem pruža detaljan uvid u postojeće studije o održivoj modi prema gore navedenim kriterijima. 


\section{KONCEPT ODRŽIVOSTI U MODI}

Prema Li, Choi i Chowu (2015.: 349), održivost se smatra iznimno aktualnom temom u istraživanjima operativnog menadžmenta modnih poduzeća obzirom da modna poduzeća posluju u djelatnosti koja prouzrokuje ekološke i društvene brige te se veliki problemi poput otpadnih voda, otpadnih tkanina, emisije štetnih tvari, prekomjerne potrošnje prirodnih resursa i korištenja ekološki neprihvatljive energije povezuju s njima.

Zadnjih nekoliko godina interes za ekološki prihvatljivim modnim proizvodima je u konstantnome porastu, naime iz perspektive kupaca modnih proizvoda sve se više pozornosti posvećuje utjacaju na okoliš i lancu stvaranja vrijednosti modnih poduzeća (Lo, Yeung i Cheng, 2012.). Ovakav trend je djelomično i posljedica niza skandala vodećih modnih brendova poput Nike-a, Levi Strauss-a, Bennetton-a, Adidas-a i C\&A optuženih, između ostaloga, za vrlo loše uvjete rada ili onečišćenja tijekom procesa proizvodnje odjeće (Caniato et al., 2012.). Danas mnoga poduzeća poput Levi Straussa-a, Nike-a, Gap-a i Eddie Bauer-a razvijaju vlastite standarde za očuvanje okoliša te su započela provoditi interne kontrole kako bi postigli razinu sukladnosti sa svojim dobavljačima (Lo, Yeung i Cheng, 2012.).

Pogotovo u industriji brze mode, mnoga poduzeća nastoje usvojiti održive strategije kako bi se postigla koordinacija između dionika i uravnotežila ekološka, ekonomska i društvena učinkovitost (Li et al., 2014.). Primjerice, H\&M je uočio da je $51 \%$ njihovoga ispuštanja $\mathrm{CO}_{2}$ u 2009. godini posljedica transporta njihovih proizvoda i u želji da smanje emisiju onečišćenja započeli su s praksom izravnih pošiljaka gdje god je to moguće, izbjegavanja privremenih skladišta i smanjenja pošiljaka morem, zrakom i željeznicom, što je rezultiralo smanjenjem emisije $\mathrm{CO}_{2}$ za više od 700 tona (Nagurney i Yu, 2012.).

Kako bi se osigurao uvid u topologiju održivosti u modi, odabrane su najvažnije definicije održivosti u kontekstu mode objavljene u relevantnim studijama u promatranome razdoblju od 2010. do 2017. (tablica 1.).

Tablica 1. Definicije i razmatranja riječi održivost (u modnom kontekstu)

\begin{tabular}{|c|l|}
\hline Autori & \multicolumn{1}{c|}{ Definicija/Razmatranja } \\
\hline $\begin{array}{c}\text { Caniato i dr. } \\
(2012 .: 661)\end{array}$ & $\begin{array}{l}\text { Održivost (u sferi mode) je odskočna daska za postizanje ekološki osvje- } \\
\text { štenoga potrošača i ojačanje cjelokupnoga imidža robne marke u razvi- } \\
\text { jenim zemljama. }\end{array}$ \\
\hline $\begin{array}{l}\text { Moda i održivost su dva naizgled kontradiktorna koncepta jer se moda } \\
\text { uvijek razvija i mijenja, dok se održivost usredotočuje na očuvanje. ... } \\
\text { Budući da je moda neverbalna reakcija na ono što se događa u svijetu, } \\
\text { ona nudi opipljivi alat za komuniciranje novih ideja i koncepata. Odr- } \\
\text { Rousso (2012.: } \\
\text { živa svijest dopušta inovativnost modnih rješenja očuvanjem okoliša, } \\
\text { uspostavljanjem zdravije ekonomije i rješavanjem društvenih nejedna- } \\
\text { kosti. Preoblikovanjem proizvodnoga procesa i generiranjem novih ide- } \\
\text { ja, moda se može proizvesti s osjećajem etike, korištenjem organskih } \\
\text { ili obnovljivih resursa i zapošljavanjem s ljudskim uvjetima rada koji } \\
\text { inzistiraju na očuvanu okoliša. Ljudi koji dizajniraju, proizvode, pro- } \\
\text { daju, kupuju i odbace odjeću, svi su dio ove globalne ekološke svijesti. }\end{array}$ \\
\hline
\end{tabular}




\begin{tabular}{|c|c|}
\hline Autori & Definicija/Razmatranja \\
\hline $\begin{array}{l}\text { Diamond J. i } \\
\text { Diamond E. } \\
(2013 .: 231)\end{array}$ & $\begin{array}{l}\text { Održiva moda je sve (povezano s odjećom ili ljepotom) što pokušava } \\
\text { smanjiti utjecaj na okoliš za razliku od tradicionalne proizvodnje odjeće } \\
\text { i potrošnje. To uključuje spektar organskih, pravednih trgovina, etičkih, } \\
\text { recikliranih i drugih rabljenih proizvoda među ostalim. }\end{array}$ \\
\hline Black (2015.) & $\begin{array}{l}\text { Održivost je koncept s mnogim definicijama, a njegova primjena u modi } \\
\text { obuhvaća različite perspektive koje obuhvaćaju sve od utjecaja materija- } \\
\text { la na okoliš, društvene pravde i pitanja koja se odnose na prava radnika } \\
\text { pa sve do ekonomije globalne modne industrije. }\end{array}$ \\
\hline $\begin{array}{l}\text { Kaiser, S. B. } \\
\quad(2015 .: \\
132-158)\end{array}$ & $\begin{array}{l}\text { Autorica definira "zelenu" kao boju nove sezone, kao simbol održivosti } \\
\text { u modi te definira koncept održive mode kao koncept koji raspoznaje } \\
\text { tenziju između kratkoročnih i dugoročnih ciljeva. }\end{array}$ \\
\hline $\begin{array}{l}\text { Li, Choi i } \\
\text { Chow (2015.: } \\
\text { 349) }\end{array}$ & $\begin{array}{l}\text { U modnoj industriji, održivost se može tretirati kao filozofija koja se } \\
\text { proširila iznad osnovne zakonske usklađenosti, ali i na odgovarajuće ko- } \\
\text { dekse ponašanja, etike i standarda poduzeća. }\end{array}$ \\
\hline $\begin{array}{l}\text { Van Dyk Ma- } \\
\text { nasseh }(2015 .: \\
\text { 268-292) }\end{array}$ & $\begin{array}{l}\text { Održiva moda je ideja koja nema usredotočeno vodstvo. Konzultanti, tr- } \\
\text { govinske udruge, akademska zajednica, trgovci, pa čak i potrošači nisu } \\
\text { dosljedni - pojedinačno ili kolektivno - sastaviti ozbiljne politike ili radnje } \\
\text { koje će omogućiti modi način da bude održiva osim povremenih i po- } \\
\text { vršnih demonstracija. Latencija modne industrije u razvijanju zajedničke } \\
\text { ideologije, koja proizlazi iz vodstva, može objasniti zašto svaki pokušaj } \\
\text { ugradnje jedinstvene kampanje za održivost jednostavno ne postoji. }\end{array}$ \\
\hline $\begin{array}{l}\text { Park i Kim } \\
(2016 .: 116)\end{array}$ & $\begin{array}{l}\text { Održive robne marke mogu se definirati kao one marke odjeće koje dje- } \\
\text { luju na principu trostruke linije }{ }^{3} \text { odnosno poslovni uspjeh se mjeri po } \\
\text { okolišnim, financijskim i društvenim kriterijima izvedbe. Održive mod- } \\
\text { ne marke proaktivno pristupaju problemu održivosti na način da su pre- } \\
\text { dane održivom poslovanju od svojih početaka s inicijativama koje sežu } \\
\text { znatno izvan jednostavnog marketinga održivih opcija. }\end{array}$ \\
\hline $\begin{array}{l}\text { Han, Seo i Ko } \\
(2017 .: 162)\end{array}$ & $\begin{array}{l}\text { Održiva moda nema jednoznačnu definiciju; međutim, koncept se op- } \\
\text { ćenito odnosi na niz poduzetničkih poduhvata koji ispravljaju različite } \\
\text { percipirane nepravde u modnoj industriji, uključujući okrutnost prema } \\
\text { životinjama, proizvodnju štetnu za okoliš i iskorištavanje radnika. }\end{array}$ \\
\hline
\end{tabular}

Izvor: autori.

\section{PROMJENA SMJERA - OD BRZOG PREMA SPOROM POIMANJU MODE}

Svatko dizajnira ako oblikuje smjer djelovanja prema promjeni postojećih situacija u one koje želimo (Simon, 1996.: 111). Danas se modna djelatnost ne prepoznaje samo zbog estetske vrijednosti i zadovoljstva koje donosi u svakidašnji život svojih konzumenata, već i zbog svoga in(direktnog) pozitivnoga i negativnoga utjecaja na svih 17 ciljeva održivog

Engl. triple-bottom line. 
razvoja koji su doneseni od strane Ujedinjenih naroda. Na primjer, prema jednom rangiranju, to je druga najprljavija industrija ${ }^{4}$ odgovorna za otprilike $10 \%$ globalne emisije ugljičnog dioksida (GCZU, 2017.), nakon djelatnosti prerade nafte i naftnih derivata. Zbog usmjerenja na masovnu proizvodnju i plasman proizvoda vrlo niskih maloprodajnih cijena, modna industrija potiče potrošače da kupuju više nego što bi trebali s jedne strane, dok s druge strane proizvođači pamuka koriste $22,5 \%$ svjetskih insekticida i $10 \%$ svih pesticida, na 2,5\% poljoprivrednoga zemljišta (www.ethicalfashionforum.com/the-issues/pesticides). Zbog tih i mnogih drugih činjenica, modna industrija se često opisuje kao industrija koja zloupotrebljava radnu snagu, intezivno koristi tehnologiju, globalizirana je, previše eksploatira prirodne resurse, iznimno je usmjerena na produktivnost te se temelji na poremećenim tržišnim trendovima i brzoj potrošnji. Ovo sve rezultira "kratkim životnim ciklusima proizvoda, velikom volatilnošću potražnje, slabom predvidljivošću prodaje i impulzivnim kupnjama" i nestabilnom potražnjom za modnim proizvodima na koju utječu čimbenici poput "vremena, najnovijih filmova, posebnih događaja i izbora slavnih osoba", proizvođači modnih proizvoda moraju puno pozornosti posvetiti ravnoteži između obje strane, ponude i potražnje (Chan, Ngai i Moon, 2017.: 486). Sa stajališta upravljanja modnim poduzećima, koncept brze mode samo nastoji izjednačiti gore navedenu ponudu i potražnju na što bolji način, a istodobno snižava razine zaliha (Choi et al., 2014.).

Brzu modu obilježava "transformacija trendovskog dizajna u artikle koje mase mogu kupiti” i "ova industrija želi privlačiti kupce u trgovine što je češće moguće kako bi povećala učestalost kupnje modnih stilova " (Turker i Altuntas, 2014.: 838). Njezin je cilj u najkraćem mogućem vremenu dopremiti odjeću u trgovine što rezultira većim brojem "sezona" (Bruce i Daly, 2006.). Brza moda se smatra neodrživom zbog toga što dovodi do prekomjerne potrošnje modnih proizvoda, jednokratnosti i slabe kvalitete proizvoda te zbog toga što njezin poslovni model povlači sa sobom mnoga socijalna i društvena pitanja kao što su iskorištavanje prirodnih resursa i pitanje uvjeta rada (Park i Kim, 2016.). S druge strane, spora moda je prilično novi održivi pokret u modnoj industriji (Jung i Jin, 2014.). Termin spora moda nastao je 2008. godine i opisuje društveno savjestan pokret koji je u sukobu sa sve bržim modnim ciklusom od svoje proizvodnje do odlaganja (Fletcher, 2014.). Spora moda se ne referira na vrijeme, kako naziv sugerira, već na filozofiju pozornosti koja je svjesna potreba svojih dionika (dionici su dizajneri, kupci, prodavači i potrošači) i utjecaja koji proizvodnja mode ima na radnike, potrošače i ekosistem (Pookulangara i Shepard, 2013.). Proizvodi spore mode su oni proizvodi koji nisu proizvedeni pod idealima poslovnog modela brze mode i općenito ne odgovaraju na brze promjene u modnim trendovima te oni postaju popularni kada se dizajneri počinju odricati modne industrije visoke frekvencije i usvajaju fleksibilan dizajn bez sezone koji se može nositi cijele godine, a time spora moda predstavlja pomak od kvantitete prema kvaliteti (Watson i Yan, 2013.).

Budući da su današnji kupci sve više zabrinuti za održivost okoliša (Li et al., 2016.), mnoga poduzeća brze mode (poput Zare, H\&M, C\&A) započela su primjenjivati lokalni pristup proizvodnji koji podrazumijeva opskrbu od strane lokalnih proizvođača, što smanjuje odgovarajući otisak ugljika, a rezultat je ekološki prihvatljiviji u odnosu na proizvodnju eksternaliziranu na udaljene lokacije (Choi et al., 2014.).

$4 \quad$ Modna industrija je jedna od najprljavijih industrija mjerena utjecajima svojih insekticida i pesticida, količinom otpada (što proizvodnoga, što otpada nakon upotrebe proizvoda), korištenjem fosilnih goriva, korištenjem agresivnih kemikalija i destrukcijom vode i tla među ostalim čimbenicima. 
Rezultat održivog pristupa modi može se naći u Novom modelu održive mode prikazanom na Shemi 1.

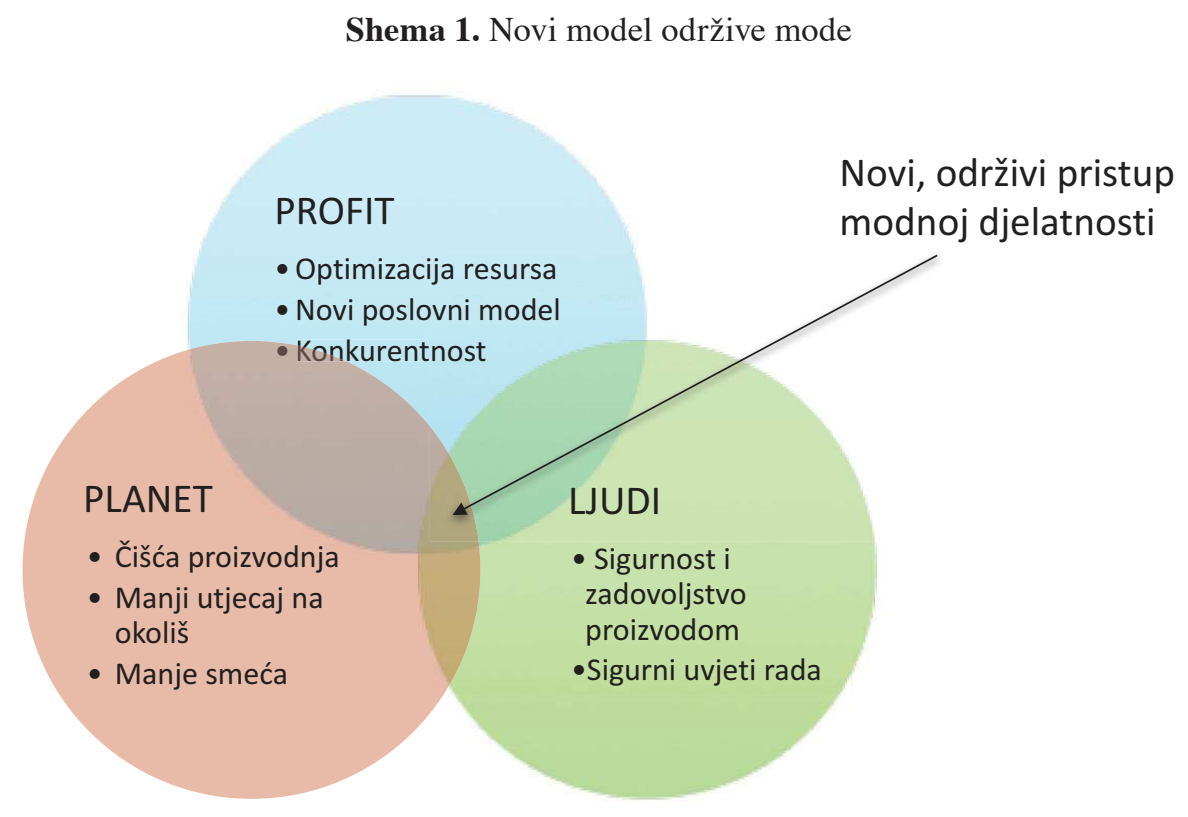

Izvor: Aako (2013.: 35).

Kao što je prikazano na shemi 1 . novi održivi modni sustav će stvoriti vrijednosti za ljude, planetu i poslovanje/profit na sljedeći način (Aako, 2013.):

- ljudi - stvaranjem sigurne sredine kroz korištenje manje kemikalija u proizvodnji, promicanjem većeg zadovoljstva proizvodom kroz kvalitetnije i dugotrajnije proizvode i promicanjem dobrobiti i sreće kroz manje materijalističku potrošnju, više socijalne pravde $\mathrm{i}$ boljih radnih uvjeta za radnike u tvornicama tekstila

- okoliš - kroz čišću proizvodnju i manje industrijske proizvodnje i otpada, prednosti za za sporije cikluse su jasne

- poslovanje - stvaranje novih modela kako bi se profit ostvarivao na ekološki prihvatljiv način.

\section{PREGLED LITERATURE O ODRŽIVOJ MODNOJ INDUSTRIJI}

U tablici 2. prikazano je indikativno razgraničenje kako bi se pojasnila metodologija i pomoglo u kreiranju sadržaja za buduća istraživanja. Ovaj pregled sadržaja postojeće literature o održivosti u modi identificira probleme istraživanja u svakome od četiri područja koja smo identificirali u postojećoj literaturi, a odnose se na područje koncepta održive mode. 
Tablica 2. Osnovna područja istraživanja o održivosti u modnoj industriji

\begin{tabular}{|c|c|}
\hline $\begin{array}{l}\text { Poslovanje modnih poduzeća } \\
\text { Formalan program utjecaja održivosti na } \\
\text { modna poduzeća pod narušenim tržištem } \\
\text { Integracija dobavljača, zelenih održivih } \\
\text { programa i financijskih rezultata modnih } \\
\text { poduzeća } \\
\text { Smjernice za dizajn i proizvodnju održivih } \\
\text { modnih proizvoda koji štede energiju }\end{array}$ & $\begin{array}{l}\text { Lanci opskrbe u modi } \\
\text { Održivo upravljanje lancem opskrbe u } \\
\text { industriji brze mode } \\
\text { Održivost okoliša u lancima opskrbe u } \\
\text { modnoj industriji } \\
\text { Okolišni i socijalni kriteriji u procjeni } \\
\text { dobavljača } \\
\text { Razvoj konkurentnog modela lanca } \\
\text { opskrbe u kojemu svako poduzeće teži } \\
\text { maksimizirati profit i minimizirati emisije } \\
\text { Procjena održivosti dobavljača }\end{array}$ \\
\hline $\begin{array}{l}\text { Modni marketing } \\
\text { Usporedba mehanizma lojalnosti između } \\
\text { održive mode i robnih marki brze mode } \\
\text { Potrošnja održivih modnih proizvoda }\end{array}$ & $\begin{array}{l}\text { Modno upravljanje } \\
\text { Utjecaj sustava upravljanja okolišem na } \\
\text { financijske rezultate u industriji mode i } \\
\text { tekstila } \\
\text { Sustav brzog odaziva i lokalne proizvodnje }\end{array}$ \\
\hline
\end{tabular}

Izvori: autori.

Matrica prikazana u tablici 3. upotrijebit će se za sažimanje publikacija s obzirom na predmet istraživanja, razinu analize, metodu istraživanja, uzorak i glavna saznanja.

Tablica 3. Matrica sadržaja održivosti u modnoj industriji

\begin{tabular}{|l|c|c|c|l|}
\hline \multicolumn{1}{|c|}{ Autor } & $\begin{array}{c}\text { Predmet } \\
\text { istraživanja }\end{array}$ & $\begin{array}{c}\text { Metoda } \\
\text { istraživanja }\end{array}$ & \multicolumn{1}{c|}{ Uzorak } & \multicolumn{1}{c|}{ Povezanost/Glavna saznanja } \\
\hline $\begin{array}{l}\text { Baskaran, } \\
\text { Nachiappan i } \\
\text { Rahman (2012.) }\end{array}$ & $\begin{array}{c}\text { Održivost lanca } \\
\text { opskrbe }\end{array}$ & Empirijsko & $\begin{array}{c}63 \text { dobavljača } \\
\text { u tekstilnoj } \\
\text { i odjevnoj } \\
\text { industriji }\end{array}$ & $\begin{array}{l}\text { Kriteriji dugog radnog vremena, onečišćenja } \\
\text { i nepoštenog tržišnog natjecanja te } \\
\text { zapošljavanje dječje radne snage ključno je za } \\
\text { dobavljače. }\end{array}$ \\
\hline $\begin{array}{l}\text { Caniato et al. } \\
(2012 .)\end{array}$ & $\begin{array}{c}\text { Održivi lanci } \\
\text { opskrbe u modi }\end{array}$ & Empirijsko & $\begin{array}{c}5 \text { modnih } \\
\text { poduzeća }\end{array}$ & $\begin{array}{l}\text { Velika poduzeća se više fokusiraju na } \\
\text { poboljšanje proizvoda i procesa, a mala } \\
\text { poduzeća su sposobna u potpunosti } \\
\text { preoblikovati svoj lanac opskrbe. }\end{array}$ \\
\hline $\begin{array}{l}\text { Lo, Yeung i } \\
\text { Cheng (2012.) }\end{array}$ & $\begin{array}{c}\text { Sustavi upravljanja } \\
\text { okolišem } \\
\text { proizvođača mode } \\
\text { i tekstila }\end{array}$ & Empirijsko & $\begin{array}{c}\text { fl modno } \\
\text { poduzeće ili } \\
\text { poduzeće } \\
\text { povezano s } \\
\text { tekstilom }\end{array}$ & $\begin{array}{l}\text { Pozitivan je utjecaj usvajanja sustava } \\
\text { upravljanja okolišem na financijske rezultate } \\
\text { poduzeća u industrijama vezanih za modu i } \\
\text { tekstil. }\end{array}$ \\
\hline $\begin{array}{l}\text { Nagurney i Yu } \\
(2012 .)\end{array}$ & $\begin{array}{c}\text { Upravljanje } \\
\text { održivim lancem } \\
\text { opskrbe u modi }\end{array}$ & $\begin{array}{l}\text { Teorijski/stu- } \\
\text { dija slučaja }\end{array}$ & $\begin{array}{l}\text { Nije } \\
\text { primjenjivo }\end{array}$ & $\begin{array}{l}\text { Razvijen je konkurentan model mrežnog } \\
\text { opskrbnog lanca, koristeći varijancijsku } \\
\text { teoriju nejednakosti koja biježi oligopolističku } \\
\text { konkurenciju diferenciranjem brandova } \\
\text { modnih proizvoda. }\end{array}$ \\
\hline
\end{tabular}




\begin{tabular}{|c|c|c|c|c|}
\hline Autor & $\begin{array}{l}\text { Predmet } \\
\text { istraživanja }\end{array}$ & $\begin{array}{c}\text { Metoda } \\
\text { istraživanja }\end{array}$ & Uzorak & Povezanost/Glavna saznanja \\
\hline Choi (2013.) & Ispuštanje ugljika & Teorijsko & $\begin{array}{l}\text { Nije } \\
\text { primjenjivo }\end{array}$ & $\begin{array}{l}\text { Pravilno provedena shema oporezivanja } \\
\text { ugljikovog dioksida od strane vladajućeg tijela } \\
\text { može uspješno privući maloprodajnog trgovca } \\
\text { da uzima proizvode od lokalnog proizvođača, } \\
\text { a može dovesti i do manjeg rizika za modnog } \\
\text { trgovca. }\end{array}$ \\
\hline $\begin{array}{l}\text { Moon et al. } \\
\text { (2013.) }\end{array}$ & $\begin{array}{l}\text { Ušteda energije u } \\
\text { modnoj industriji }\end{array}$ & Empirijsko & 301 poduzeće & $\begin{array}{l}\text { Sustavni i logistički postupak za identificiranje } \\
\text { energetskih čimbenika za održivu modu. }\end{array}$ \\
\hline $\begin{array}{l}\text { Turker i } \\
\text { Altuntas } \\
\text { (2014.) }\end{array}$ & $\begin{array}{l}\text { Održivi lanci } \\
\text { opskrbe u modi }\end{array}$ & Teorijsko & 9 poduzeća & $\begin{array}{l}\text { Poduzeća se značajno usredotočuju na } \\
\text { pridržavanje dobavljača njihovim kodeksima } \\
\text { ponašanja, primjenjujući daljnje aktivnosti } \\
\text { nadzora i praćenja s ciljem sprječavanja } \\
\text { problema u proizvodnji u zemljama u razvoju, } \\
\text { ukupnog poboljšanja učinkovitosti lanca } \\
\text { opskrbe i postavljanja kriterija održivosti za } \\
\text { svoje dobavljače. }\end{array}$ \\
\hline Li et al. (2014.) & $\begin{array}{l}\text { Održivi lanci } \\
\text { opskrbe u modi }\end{array}$ & $\begin{array}{l}\text { Studija } \\
\text { slučaja }\end{array}$ & $\begin{array}{l}\text { Nije } \\
\text { primjenljivo }\end{array}$ & $\begin{array}{l}\text { Temeljni utjecaj i srce poduzeća trebalo bi se } \\
\text { ojačati iz perspektive unutarnjeg upravljanja, a } \\
\text { dionici bi trebali surađivati kako bi se postigla } \\
\text { održivost upravljanja kroz cijeli lanac opskrbe } \\
\text { brze mode iz perspektive vanjskog upravljanja. }\end{array}$ \\
\hline $\begin{array}{l}\text { Li, Choi i Chow } \\
\text { (2015.) }\end{array}$ & Modno poslovanje & Empirijsko & $\begin{array}{l}45 \text { izlistanih } \\
\text { modnih } \\
\text { poduzeća }\end{array}$ & $\begin{array}{l}\text { Modna poduzeća koja nisu uspostavila } \\
\text { formalne programe održivosti posluju relativno } \\
\text { uspješno u uvjetima poremećenog tržǐ̌ta. }\end{array}$ \\
\hline Li et al. (2016.) & Modno poslovanje & Empirijsko & $\begin{array}{l}90 \text { modnih } \\
\text { poduzeća }\end{array}$ & $\begin{array}{l}\text { Udruživanje dobavljača (SI) i usvajanje } \\
\text { programa zelene održivosti mogu značajno } \\
\text { poboljšati financijske rezultate modnog } \\
\text { poduzeća; pomažu ublažiti štetni učinak } \\
\text { financijskog tsunamija na financijske rezultate } \\
\text { modnog poduzeća. }\end{array}$ \\
\hline $\begin{array}{l}\text { Park i Kim } \\
\text { (2016.) }\end{array}$ & $\begin{array}{l}\text { Odjevne robne } \\
\text { marke u održivosti }\end{array}$ & Empirijsko & $\begin{array}{l}556 \text { ispitanika } \\
\text { iz SAD-a }\end{array}$ & $\begin{array}{l}\text { Potrošači formiraju lojalnost robnoj marki } \\
\text { održive mode, nasuprot brzoj modi na } \\
\text { drugačiji način. }\end{array}$ \\
\hline $\begin{array}{l}\text { Winter i Lasch } \\
\text { (2016.) }\end{array}$ & $\begin{array}{c}\text { Okolišni i socijalni } \\
\text { kriteriji u procjeni } \\
\text { dobavljača }\end{array}$ & $\begin{array}{l}\text { Studija } \\
\text { slučaja }\end{array}$ & $\begin{array}{l}6 \text { modnih } \\
\text { i odjevnih } \\
\text { poduzeća }\end{array}$ & $\begin{array}{l}\text { Važnost socijalnih i ekoloških kriterija pri } \\
\text { procjeni dobavljača. }\end{array}$ \\
\hline $\begin{array}{l}\text { Han, Seo i Ko } \\
\text { (2017.) }\end{array}$ & $\begin{array}{l}\text { Potrošnja održivih } \\
\text { modnih proizvoda }\end{array}$ & Empirijsko & $\begin{array}{l}12 \text { muškara i } \\
12 \text { žena }\end{array}$ & $\begin{array}{l}\text { Utvrđena iskustva omogućuju modnim } \\
\text { potrošačima da steknu praktično iskustvo } \\
\text { o održivoj modi i postanu otvoreniji za } \\
\text { prihvaćanje održivih potrošačkih navika } \\
\text { prilikom potrošnje modnih proizvoda. }\end{array}$ \\
\hline
\end{tabular}

Izvor: autori. 
Kao što se može vidjeti iz matrice, pronađeno je samo 13 znanstvenih radova u ScienceDirect bazi podataka koji su usmjereni na probleme održivosti u modnoj industriji. Od ukupnoga broja analiziranih radova, tri su teorijska, osam je empirijskih i dva su studije slučaja. Pregled studija s obzirom na predmet istraživanja koji pokrivaju prikazan je u tablici 4 .

Tablica 4. Predmeti istraživanja u studijama o održivoj modi

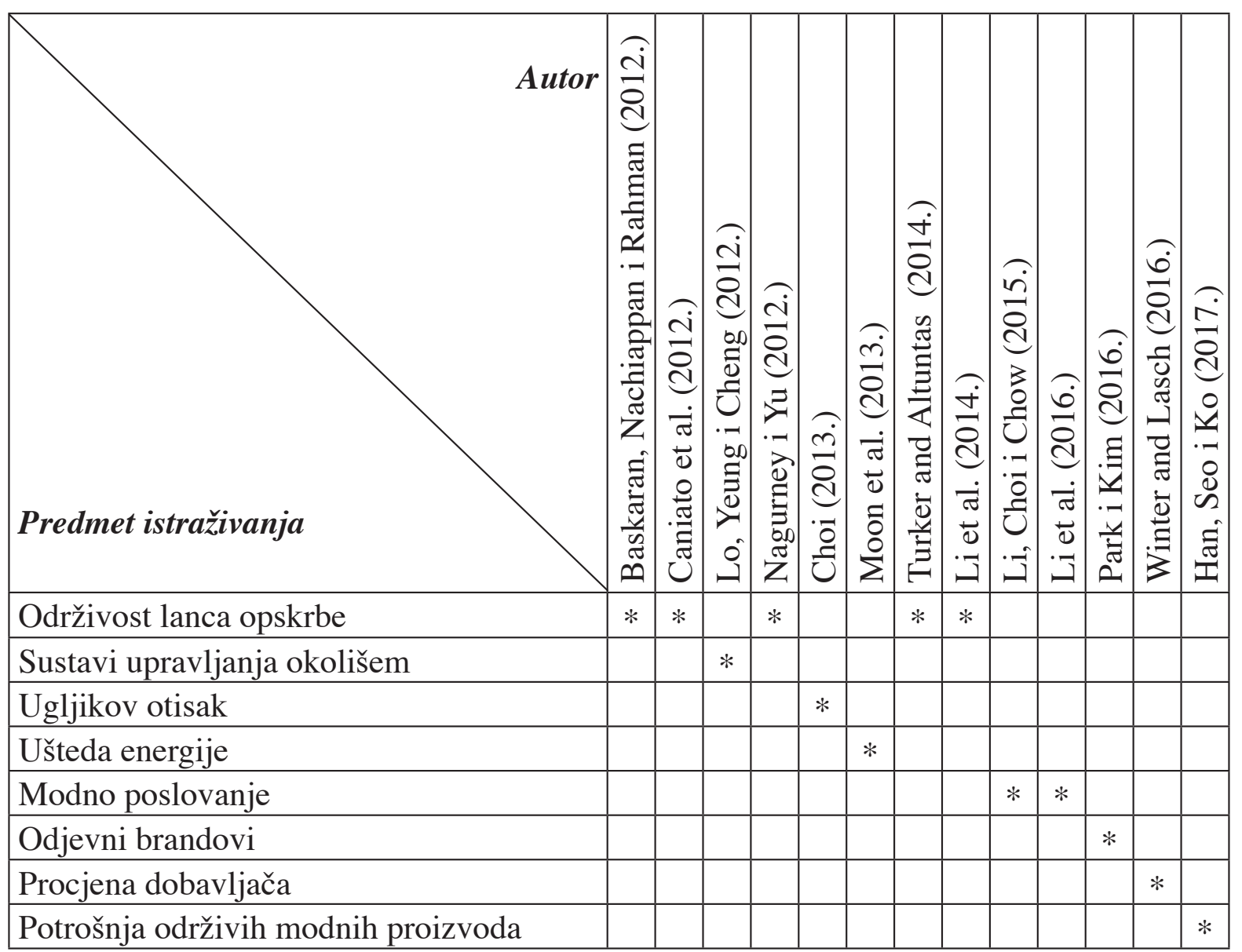

Izvor: autori.

\section{ZAKLJUČAK}

Moda je prilično složena djelatnost zbog mnogih čimbenika koji utječu na proces izgradnje vrijednosti, a koji uključuje duge i različite opskrbne lance od uzgoja usjeva, proizvodnje sirovina, proizvodnje tekstila, dizajniranja odjeće, razvoja veličina, marketinga i promocije, distribucije, maloprodaje, isporuke, korištenja i konačno odbacivanja odjeće. Sadašnji poslovni model modne maloprodaje, kao što je prethodno opisano, stvara veliku potražnju za brzim dizajnom, niskom kvalitetom i cijenom te stoga stvara velike probleme uglavnom iz okolišne, ali i iz društvene i ekonomske perspektive.

Ovaj članak je preduvjet za empirijsko istraživanje utjecaja različitih elemenata društveno-odgovornog poslovanja na poslovanje poduzeća u modnoj industriji (tekstilna, 
odjevna i obućarska poduzeća) u Republici Hrvatskoj. Isto istraživanje bi trebalo imati za ključne ciljeve: prepoznavanje ključnih elemenata utjecaja društveno-odgovornog poslovanja na poduzeća u modnoj industriji; oblikovanje i empirijsko potvrđivanje modela utjecaja društveno-odgovornog poslovanja na poslovanje modnih poduzeća; prepoznavanje moderirajućih varijabli (poput vlasničke strukture, strukture menadžmenta, veličine i starosti poduzeća) na pretpostavljene pozitivne veze; te determiniranje menadžerske implikacije za promatrana poduzeća, a koje bi mogla doprinijeti uspješnosti poslovanja i izgradnji modela izvrsnosti na održivim temeljima. Takvi rezultati bi mogli pomoći u razvitku ekonomskih kapaciteta promatranih djelatnosti, kao i implementaciji elemenata društveno-odgovornog poslovanja u modnu industriju koja je prepoznata kao veliki zagađivač okoliša. Očekivani doprinos ovakvoga pristupa trebao bi se ogledati u oblikovanju novoga modela pretpostavljenih veza; razvoju novih teorijskih i empirijskih spoznaja o ključnim elementima društveno-odgovornog poslovanja u hrvatskoj modnoj djelatnosti, kvalitetnijem shvaćanju praktičnih koristi od primjene društveno-odgovornog koncepta poslovanja i predstavljanju smjernica za njihovu primjenu na dobrobit poduzeća, cjelokupne djelatnosti i lokalne zajednice.

Važnost istraživanja se ogleda u činjenici da društveno-odgovorno poslovanje predstavlja iznimno važnu i propulzivnu tematiku strateških istraživanja iz područja konkurentnosti i strateškog menadžmenta te je posebno aktualno u modnoj industriji. Primjena društveno-odgovornog koncepta poslovanja ne samo da može pospješiti reputaciju i imidž modnog poduzeća u suvremenom društvu već se primjenom suvremenih poslovnih koncepata vezanih uz odgovorno poslovanje može pozitivno utjecati na njegove inovacijske kapacitete, motiviranost i angažiranost zaposlenika, lojalnost kupaca, menadžment ključnih rizika, menadžment dionika, povoljnije financijske tijekove te sumarno uspješnost i održivost poslovnog modela. Unatoč tome, u postojećoj znanstvenoj literaturi nedostaju istraživanja koja empirijski integriraju elemente društveno-odgovornog poslovanja u jedinstveni teorijski koncept/okvir uz uspješnost poduzeća modne djelatnosti u tranzicijskoj ekonomiji. Nadovezujući se na taj jaz u literaturi te uvažavajući sve specifičnosti modne djelatnosti, potrebno je utvrditi prisutnost koncepta društveno-odgovornog poslovanja u hrvatskoj modi te sugerirati održivi način moguće aplikacije koncepta.

\section{LITERATURA:}

1. Aako, M. 2013. What is the Role of Aesthetics in Sustainability?, Book: Sustainable Fashion: New Approaches, ed: Niinimäki, K., Aalto University publication series Art + Design + Architecture 9/2013 Aalto ARTS Books Helsinki, Finland.

2. Baskaran, V., Nachiappan, S. i Rahman, S. 2012. Indian textile suppliers' sustainability evaluation using the grey approach, International Journal of Production Economics 135(2): 647-658.

3. Black, S. 2015., Fashion and Sustainability, Bibliographical Guides. London: Bloomsbury Academic, 2015. Bloomsbury Fashion Central. Web. 30 Oct. 2017. <http://dx.doi. org/10.5040/9781474280655-BG008>.

4. Bruce, M. i Daly, L. 2006. Buyer behaviour for fast fashion, Journal of Fashion Marketing and Management, 10(3): 329-344. 
5. Caniato, F., Caridi, M., Crippa, L. i Moretto, A. 2012. Environmental sustainability in fashion supply chains: An exploratory case based research, International Journal of Production Economics 135(2): 659-670.

6. Chan, A. T. L., Ngai, E. W. T. i Moon, K. L. M. 2017. The Effects of Strategic and Manufacturing Flexibilities and Supply Chain Agility on Firm Performance in the Fashion Industry, European Journal of Operational Research, 259(2): 486-499.

7. Choi, T.-M. 2013. Local sourcing and fashion quick response system: The impacts of carbon footprint tax, Transportation Research Part E: Logistics and Transportation Review, 55(C): 43-54.

8. Choi, T.-M., Chiu, C.-H., Govindan, K. i Yue, X. 2014. Sustainable fashion supply chain management: the European scenario, European Management Journal 32(5): 821-822.

9. Diamond, J. i Diamond, E. 2013. Sustainable Fashion: An Eco-Friendly Movement, The World of Fashion. London: Fairchild Publications, 2013. 215-231. Bloomsbury Fashion Central. Web. 30 Oct. 2017. <http://dx.doi.org/10.5040/9781501304309.ch-009>.

10. Ethical Fashion Forum, dostupno na: goo.gl/PBZh13 (27.4.2017.)

11. Fletcher, K. 2014. Sustainable Fashion and Textiles: Design Journeys, $2^{\text {nd }}$ edition, Routledge: Abingdon and New York. GCU, The Fair Fashion Centar, dostupno na: goo.gl/1Krxv2 (29.4.2017)

12. Han, J., Seo, Y. i Ko, E. 2017. Staging luxury experiences for understanding sustainable fashion consumption: A balance theory application, Journal of Business Research, 74 (C): 162-167.

13. IO Ivana Omazić, dostupno na: www.ioivanaomazic.com/about (27. 4. 2017.).

14. Jung, S. i Jin, B. 2014., A theoretical investigation of slow fashion: sustainable future of the apparel industry, International Journal of Consumer Studies, 38(5): 510-519.

15. Kaiser, S. B. 2015. Mixing Metaphors in the Fiber, Textile, and Apparel Complex:

16. Moving Forward. U: Hethorn, J. i Ulasewicz, C. (ur.) Sustainable Fashion What's Next?: A Conversation about Issues, Practices and Possibilities. Fairchild Books: London, 132-158.

17. Kawamura, Y. 2010. The Fashion Industry. U: Eicher, J. B. i Tortora P. G. (ur.) Berg Encyclopedia of World Dress and Fashion: Global Perspectives, Berg: Oxford, 191-203.

18. Li, Y., Zhao, X., Shi, D. i Li, X. 2014. Governance of sustainable supply chains in the fast fashion industry, European Management Journal, 32(5): 823-836.

19. Li, W.-Y., Choi, T.-M. i Chow, P.-S. 2015. Risk and benefits brought by formal sustainability programs on fashion enterprises under market disruption, Resources, Conservation and Recycling, 104(B): 348-353.

20. Li, W.-Y., Chow, P.-S., Choi, T.-M. i Chan, H.-L. 2016. Supplier integration, green sustainability programs, and financial performance of fashion enterprises under global financial crisis, Journal of Cleaner Production, 135(1): 57-70.

21. Lo, C. K. Y., Yeung, A. C. L. i Cheng, T. C. E. 2012. The impact of environmental management systems on financial performance in fashion and textiles industries, International Journal of Production Economics 135(2): 561-567. 
22. Moon, K. K.-L., Youn, C., Chang, J. M. T. i Yeung, A. W.-H. 2013. Product design scenarios for energy saving: A case study of fashion apparel, International Journal of Production Economics 146(2): 392-401.

23. Moore, G. 2012. Basics Fashion Management 02: Fashion Promotion: Building a Brand Through Marketing and Communication. AVA Book: Lausanne.

24. Nagurney, A. i Yu, M. 2012. Sustainable fashion supply chain management under oligopolistic competition and brand differentiation, International Journal of Production Economics 135(2): 532-540.

25. Park, H. i Kim, Y.-K. 2016. Proactive versus reactive apparel brands in sustainability: Influences on brand loyalty, Journal of Retailing and Consumer Services, 29: 114122.

26. Pookulangara, S. i Shepard, A. 2013. Slow fashion movement: Understanding consumer perceptions - An exploratory study, Journal of Retailing and Consumer Services, 20: 200-206.

27. Rousso, C. 2012. Fashion Forward: A Guide to Fashion Forecasting. Fairchild Publications: London.

28. Simon, H. A. (1996): The Sciences of the Artificial, $3^{\text {rd }}$ edition, The MIT Press: Cambridge and London.

29. Turker, D. i Altuntas, C. 2014. Sustainable supply chain management in the fast fashion industry: An analysis of corporate reports, European Management Journal, 32(5): 837-849.

30. Van Dyk Manasseh, L. 2015. Treatise for Fashion Sustainable Thinking. U: Hethorn, J. i Ulasewicz, C. (ur.) Sustainable Fashion What's Next?: A Conversation about Issues, Practices and Possibilities. Fairchild Books: London, 268-292.

31. Watson, M. Z. i Yan, R-N. 2013. An exploratory study of the decision processes of fast versus slow fashion consumers, Journal of Fashion Marketing and Management, 17(2), 141-159.

33. Wilson, E. 2010. Fashion Industry. U: Steele, V. (ur.) The Berg Companion to Fashion. Berg: New York, 290-293.

34. Winter, S. i Lasch, R. 2016. Environmental and social criteria in supplier evaluationLessons from the fashion and apparel industry, Journal of Cleaner Production, Volume 139: 175-190. 